\title{
Diversity and emergence of new variants of African swine fever virus Genotype I circulating in domestic pigs in Nigeria (2016-2018)
}

\author{
Adeyinka Adedeji ${ }^{1}$, Anvou Jambol ${ }^{1}$, R. Weka ${ }^{1}$, Muwanika V.B. ${ }^{2}$, Pam Luka ${ }^{1}$, and Charles \\ Masembe $^{3}$ \\ ${ }^{1}$ National Veterinary Research Institute \\ ${ }^{2}$ Makerere University College of Agricultural and Environmental Sciences \\ ${ }^{3}$ Makerere University
}

December 31, 2021

\begin{abstract}
African swine fever (ASF) is the most lethal disease of pigs caused by ASF virus (ASFV) with severe economic implications and threat to food security in endemic countries. Between 2016 and 2018, several ASF outbreaks were reported throughout pig producing States in Nigeria. This study was designed to identify the ASFV genotypes responsible for these outbreaks and the transmission pathways of the virus during this period. Twenty-two ASFV-positive samples collected during passive surveillance in eight States of Nigeria were characterized using 3 partial genes sequences of the virus. The genes were: $p 72$ capsid protein of the B646L, p54 envelope protein of E183L, and the central variable region (CVR) within B602L of ASFV. Phylogenetic analysis based on $p 72$ and $p 54$ revealed ASFV genotype I as the circulating virus. Sequence analysis of the CVR of B602L revealed genetic variations with six ASFV variants namely: Tet-15, Tet-20a, Tet-21b, Tet-27, Tet-31 and Tet-34, thus increasing the overall genetic diversity of ASFV in Nigeria. Three of these variants: Tet-21b, Tet-31 and Tet-34 were identified for the first time in Nigeria. The new variants of ASFV genotype I were identified in the States of Enugu, Imo, Plateau and Taraba, while co-circulation of multiple variants of ASFV genotype I were recorded in Plateau and Benue States. The high genetic diversity, emergence and increasing recovery of new variants of genotype I in Nigeria should be a concern given that ASFV is a relatively stable DNA virus. The epidemiological implications of these findings require further investigation.
\end{abstract}

Diversity and emergence of new variants of African swine fever virus Genotype I circulating in domestic pigs in Nigeria (2016-2018)

Adedeji A.J., ${ }^{1,2}$ A. R. Jambol,,${ }^{1}{ }^{2}$ R. Weka, ${ }^{1}$ V.B., Muwanika, ${ }^{3}$ P.D. Luka, ${ }^{1}$ and C. Masembe ${ }^{2 *}$

${ }^{1}$ National Veterinary Research Institute, PMB 01, Vom, Nigeria

${ }^{3}$ College of Agricultural \& Environmental Sciences, Makerere University, P. O. Box 7062 Kampala, Uganda

${ }^{2}$ College of Natural Sciences, Makerere University, P. O. Box 7062, Kampala, Kampala, Uganda

\section{Summary}

African swine fever (ASF) is the most lethal disease of pigs caused by ASF virus (ASFV) with severe economic implications and threat to food security in endemic countries. Between 2016 and 2018, several ASF outbreaks were reported throughout pig producing States in Nigeria. This study was designed to identify the ASFV genotypes responsible for these outbreaks and the transmission pathways of the virus during this period. Twenty-two ASFV-positive samples collected during passive surveillance in eight States of Nigeria were characterized using 3 partial genes sequences of the virus. The genes were: $p^{72}$ capsid protein of the $B 646 L$, p54 envelope protein of E183L, and the central variable region (CVR) within B602L of ASFV. Phylogenetic 
analysis based on $p 72$ and $p 54$ revealed ASFV genotype I as the circulating virus. Sequence analysis of the CVR of B602Lrevealed genetic variations with six ASFV variants namely: Tet-15, Tet-20a, Tet-21b, Tet-27, Tet-31 and Tet-34, thus increasing the overall genetic diversity of ASFV in Nigeria. Three of these variants: Tet-21b, Tet-31 and Tet-34 were identified for the first time in Nigeria. The new variants of ASFV genotype I were identified in the States of Enugu, Imo, Plateau and Taraba, while co-circulation of multiple variants of ASFV genotype I were recorded in Plateau and Benue States. The high genetic diversity, emergence and increasing recovery of new variants of genotype I in Nigeria should be a concern given that ASFV is a relatively stable DNA virus. The epidemiological implications of these findings require further investigation.

Keywords: African swine fever, transmission pathway, multiple variants

\section{*Correspondence: Charles.masembe@mak.ac.ug}

\section{Introduction}

African swine fever (ASF) is a highly fatal haemorrhagic disease of domestic pigs caused by the ASF virus (ASFV), resulting in severe morbidity and mortality (Odemuyiwa et al., 2000; Penrith \& Vosloo, 2009). ASFV is a unique double-stranded DNA virus, and the sole member of the genus Asfivirus and family Asfarviridae (Alonso et al., 2018). ASF was first reported in Kenya in 1921, after which the disease was reported in other parts of Africa (Brown et al., 2017; Montgomery, 1921; Mulumba-Mfumu et al., 2019). The disease was initially restricted to Africa, but now has spread to Europe, Asia, and Oceania (Dellicour et al., 2020; Dixon et al., 2020). ASFV is transmitted by direct and indirect contact between pigs in the ASFV domestic cycle, soft ticks of the genus: Ornithodoros spp in the tick transmission cycle, and via warthogs in the sylvatic cycle (Costard et al., 2013; Jori et al., 2013). Currently, genetic typing of ASF viruses is carried out through partial nucleotide sequencing of the p72 capsid protein of the $B 646 \mathrm{~L}$ gene and full-length of envelope protein p54 of the E183L gene (Bastos et al., 2003; Lubisi et al., 2005). Further differentiation of ASFV genotypes can be done using the central variable region (CVR) of the B602L gene (Gallardo et al., 2009). Based on the sequence analysis of the 72 capsid protein of the $B 646 \mathrm{~L}$ gene, 24 genotypes of ASFV have been identified (Blome et al., 2020). However, multiple genotypes in a geographical region are associated with tick and sylvatic transmission cycles of ASF mostly reported in East and Southern Africa regions (Costard et al., 2013; Quembo et al., 2018). Molecular characterization of B646L, E183L, and B602L of the ASFV can be used for investigating the source and extent of outbreaks and possible genetic diversity of circulating viral strains (Lubisi et al., 2005; Malogolovkin, Burmakina, Titov, et al., 2015). ASFV is a relatively stable DNA virus with low mutation rates and coupled with lack of closely related viruses which reduces the risk of high genetic variation (Dixon et al., 2020; Gaudreault et al., 2020). However, certain regions of the virus such as the CVR are prone to mutations leading to the creation of new ASFV variants (Luka et al., 2016). These new variants might have implications for tracing and tracking the rate of ASF infections across time and space. In the absence of a vaccine or any other therapy, it is very important to mitigate the spread of the disease by tracking sources of outbreaks and instituting swift control measures particularly in endemic countries. Following the introduction of ASF into Nigeria in 1997, the disease is now endemic in the country with frequent reports of outbreaks in pig producing areas of the country (Odemuyiwa et al., 2000; Owolodun et al., 2010). Previous studies have identified genotype I as the only ASFV circulating in Nigeria and other West African countries before ASFV genotype II was reported in Nigeria recently (Adedeji et al., 2021; Couacy-Hymann et al., 2019; Tizhe et al., 2020). However, different variants of the ASFV genotype I based on the CVR within the B602L gene have been recovered from outbreaks due to possible mutation in that genetic region of the virus. Between years 1997 and 2015, eleven (11) ASFV genotype I variants have been recovered from outbreaks in Nigeria (Couacy-Hymann et al., 2019; Luka et al., 2016; Owolodun et al., 2010). The ASF disease situation in the country has been complicated by poor husbandry system, unrestricted live pig movement, and a weak veterinary system. Despite several studies, the epidemiology and probable drivers of the disease in Nigeria are poorly understood (Awosanya et al., 2015; Fasina et al., 2012). Between 2016 and 2018, there was an upsurge in reported cases of ASF in Nigeria affecting eight States of the country. Epidemiological investigations revealed limited understanding of how ASFV spread into and within farming communities. Therefore, this study carried out the genetic characterization of circulating ASFV to shed 
light on possible insights on the course and characteristics of these outbreaks.

\section{Materials and methods}

\section{Study area}

Nigeria is bordered by Benin Republic, Niger Republic, Chad, Cameroon, and the Atlantic Ocean to the southern part. Nigeria's porous international borders with neighbouring countries make trans-border trading easy with free movement of livestock in both directions. Administratively, Nigeria is divided into 36 states and the Federal Capital Territory (FCT), Abuja. Pig production activities are carried out in parts of 30 States of the country either as commercial/backyard intensive farms or free-roaming extensive pig production systems (Fasina et al., 2012). Due to the high demand for live pigs, mobility of these animals is unregulated usually from the North-Central to the Southern coastal parts of the country where farmers and traders can obtain higher prices for their animals.

\section{ASF outbreak investigations and sample collection}

Between 2016 and 2018), 37 ASF outbreaks were reported in domestic pigs in 8 States of Nigeria (Fig 1). One hundred ten (110) outbreak samples were collected consisting of whole blood and tissue (liver, spleen, and lymph nodes) from 147 pig farms. The affected States were Abia, Benue, Enugu, Kaduna, Imo, Lagos, Plateau, and Taraba States (Fig. 1, Table 1). Samples were collected at intensive pig farms and free-roaming pigs in the affected States of the country. Laboratory diagnosis was carried at the ASF National Reference Laboratory (NRL) at the National Veterinary Research Institute (NVRI), Vom, Nigeria. Epidemiological investigations were carried out in all affected States. In 2016, ASF was reported in three States of Nigeria including: Benue, Kaduna, and Plateau States. One of the ASF outbreaks in Plateau State was reported in an institutional farm and the source of viral introduction was through farm workers. Three States (Abia, Imo, and Enugu) in Eastern Nigeria with contiguous common border reported ASF outbreaks in 2017. ASF outbreak in Imo State occurred due to the introduction of pigs from the Republic of Cameroon. The outbreak affected a cluster of seven intensive pig farms with a herd size of 60-1000 pigs and recorded mortality of $73 \%$ (2168/2930). A similar outbreak of ASF also occurred in neighbouring Abia State in a cluster of nine farms and a mortality rate of $80 \%(845 / 1050)$ was recorded in exotic breeds of pigs. The ASF outbreak started in one of the farms and it spread to other farms through the activities of butchers who also kept pigs. The ASF outbreak in Enugu State was also in an intensive small-holder pig farm. Similarly, ASF outbreaks were reported in 2018 in 3 Northern States (Benue, Taraba, and Plateau) with common boundaries (Fig 1). The outbreak started in Plateau State and was reported between April and November 2018 in small-holder intensive pig farms mostly in Jos-South Local Government Area (LGA) (Fig 1). Also in September 2018, the disease was reported in Zing, Taraba State, ASF affected 101 pig farmers with recorded mortality of 45.6\% (3354/7360) pigs. Affected animals were mainly free-roaming Nigerian indigenous pig (NIP) breeds. In addition, widespread ASF outbreaks were reported in four major locations of Gboko, Otukpo, Yandev, and Makurdi, all in Benue State from June to December 2018. The affected pig farms were breeder and smallholder intensive farms. Lastly, in southwestern Nigeria, Lagos State recorded ASF outbreak close to the Nigeria-Benin republic international border in an intensive pig farm in 2018 with $75 \%$ (40/60) mortality.

\section{Laboratory analysis}

The tissue samples were homogenized and total genomic DNA was extracted from tissue and blood samples using QIAamp DNA mini kit (Qiagen, Hilden, Germany) following the manufacturer's instructions. ASF diagnosis was carried out by detection of ASFV genome using conventional polymerase chain reaction (PCR) using primers PPA1: 5'-AGT TAT GGG AAA CCC GAC CC-3' and PPA2 5'-CCC TGA ATC GGA GCA TCC T-3', targeting the B646L gene of the ASFV as previously described (Agüero et al., 2003). Amplified PCR products were separated and visualized by gel electrophoresis, with $257 \mathrm{bp}$ being the expected PCR product

\section{Molecular Characterization of African swine fever virus}

For ASFV genotyping and assessing the patterns of genetic variation among ASFV positive samples, three 
regions within the ASFV genome were PCR amplified and sequenced. These were the C-terminal end of the $B 646 \mathrm{~L}$ gene encoding the $p 72$ protein, the full length of $E 183 \mathrm{~L}$ gene encoding $p 54$ protein, and CVR within theB602L gene as previously described (Bastos et al., 2003; Lubisi et al., 2005; Phologane et al., 2005 ; Nix et al., 2006; Gallardo et al., 2009). The PCR products were purified using MinElute PCR purification kit (Qiagen) as described by the manufacturer's protocol and characterized commercially at Macrogen Inc. (Netherlands Europe) using Sanger sequencing method. The assemblage of sequence reads was carried out using the Staden software package (http://staden.sourceforge.net/) and Bioedit (Hall, 1995) with default settings. Confirmation of sequences type was carried out using the BLAST tool, (https://blast.ncbi.nlm.nih.gov/Blast.cgi). Phylogenetic trees were constructed using MEGA X and inferred using Neighbour Joining method for $p$ 72 and Minimum Evolution method for $p 54$ (Kumar et al., 2018). ASFV genotypes were retrieved from the Genbank for the construction of the phylogenetic trees for both $p 72$ and $p 54$. All ASFV sequences from this study were submitted to the Genbank under accession numbers: OL621859- OL621879 for B646Lgene, OL621880- OL621896 for E183L and OL638971-OL638986 for

\section{B602L}

The sequences of the ASFV B602L gene from this study were translated to protein sequences using ExPASy (https ://web.expas y.org/translate/) with default settings. The translated amino acid tetramers were matched with published codes as previously reported (Achenbach et al., 2017; Nix et al., 2006). The tetrameric repeat sequences (TRS) from this study were compared with 25 TRS recovered in Nigeria and other West African countries.

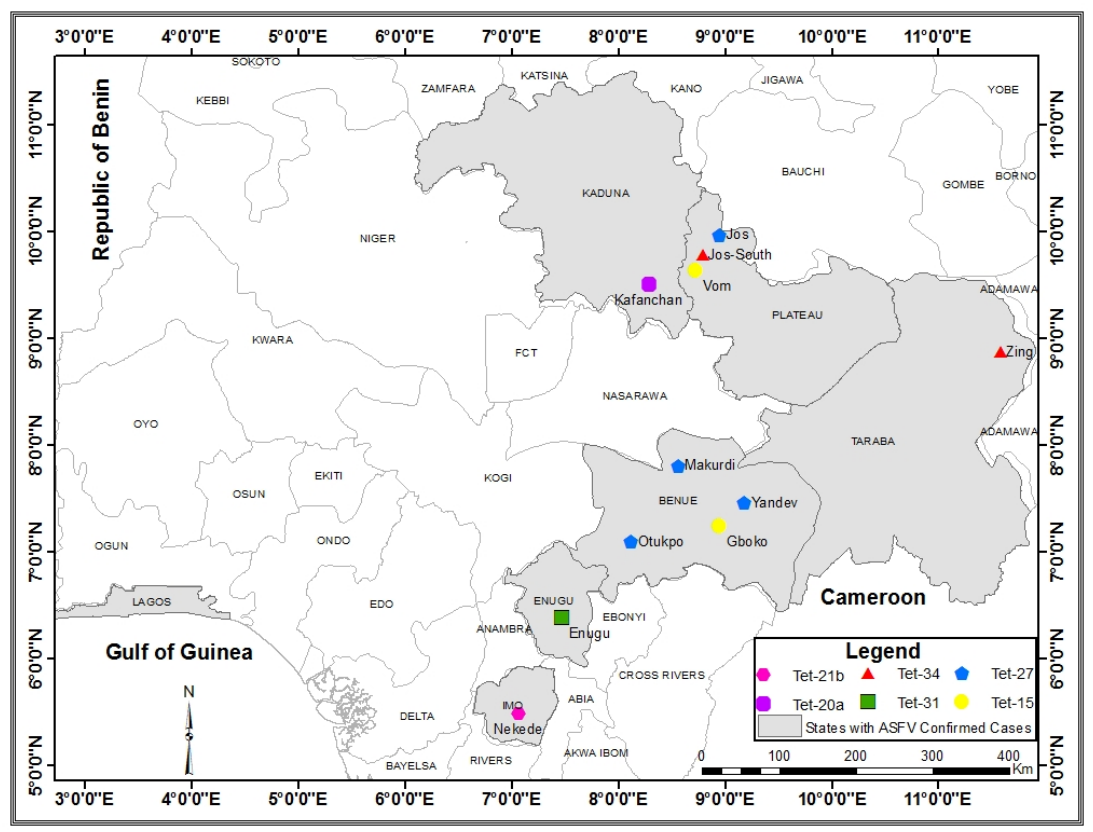

Fig 1: Map of Nigeria showing the distribution of African swine fever virus genotype I variants recovered from outbreaks between 2016 and 2018

\section{Results}

\section{Laboratory Results}

From the 110 samples collected within the three years study period, laboratory analysis by conventional PCR indicated that in $42.5 \%$ (38/110) of samples collected ASFV was detected. The positive samples were 
distributed in the respective states as follows: Abia (1) Benue (12), Enugu (2), Kaduna (1), Imo (2), Lagos (2), Plateau (16) and Taraba (2), ASF cases in 2016 was confirmed in Benue, Kaduna and Plateau States. The ASF outbreak in 2017 was in Abia, Imo and Enugu States. While, in 2018 the ASF outbreak was in Benue, Lagos, Plateau, and Taraba States.

Table 1: Distribution of African swine fever outbreaks, samples collected, laboratory results in eight States of Nigeria from 2016 to 2018

\begin{tabular}{lllll}
\hline Year & State & No of outbreaks & Samples collected & Positive samples by PCR \\
\hline 2016 & Benue & 1 & 2 & 1 \\
& Kaduna & 1 & 2 & 1 \\
\multirow{2}{*}{2017} & Plateau & 3 & 10 & 2 \\
& Abia & 1 & 1 & 1 \\
& Enugu & 1 & 2 & 2 \\
2018 & Imo & 1 & 2 & 2 \\
& Benue & 11 & 38 & 11 \\
& Lagos & 1 & 2 & 2 \\
& Plateau & 16 & 47 & 14 \\
Total & Taraba & 1 & 4 & 2 \\
\hline
\end{tabular}

\section{Phylogenetic analysis of $B 646 L$ of ASFV}

The $p 72$ of $B 646 L$ gene sequences generated from this study when compared with other sequences in the GenBank, revealed a 99-100\% similar to ASF viruses from Cameroon (MG596409, MG596420) and Ivory Coast (MG674296) using the BLAST search tool. Phylogenetic analysis of the Nigerian sequences with representatives of the 18 out 24 genotypes showed sequences generated in this study clustered with genotype 1 (Fig 2).

\section{Phylogenetic analysis of E183L (p54) of ASFV}

The phylogenetic analysis of the $p 54$ protein of ASFV revealed that all Nigerian sequences clustered with some sequences from West African countries belonging to genotype 1a (Fig 3). The phylogenetic tree was constructed using sequences of 16 genotypes retrieved from the Genbank. Comparison of sequences from this study and recent sequences from other West African countries showed 99-100\% similarity with sequences from Cameroon (MG596464, MG596468), Ivory Coast (MH836355), and Mali (MT886241).

\section{Sequence analysis of the CVR of B602L}

Sequence analysis of the CVR of the B602L gene recovered six ASFV variants with distinct TRS named as: Tet-15, Tet-20a, Tet-21, Tet-27b, Tet-31 and Tet-34 (Table 2). ASF variants Tet-15, Tet-20a, Tet-27 had been previously reported in Nigeria (Table 2). While, Tet-21b, Tet-31, and Tet-34 were the new variants that are being reported for the first time in Nigeria and West Africa in this study. The Nigerian Isolates KASIT_2, recovered from a live pig market in Katsit, Kaduna State is similar to Cameroonian ASFV (AF513045) (Table 2). Plateau State had the highest number (3) of co-circulating ASFV TRS variants (Tet-15, Tet-27, Tet-34) followed by Benue State with two (Tet-15 and Tet-27). Interestingly, Tet-34 that was circulating in pig farms between April and November 2018 in Plateau State was also recovered in Zing, Taraba State in September 2018 possibly introduced from Plateau State via movement of live pigs. ASFV TRS variant Tet-31 recovered from Enugu State has not been previously reported in Nigeria, but the source of infection is unknown due to limited epidemiological information. Tet- 15 was the only ASFV genotype I variant recovered in two separate years of this study, it was circulating in two States (Plateau and Benue). Tet-21b recovered from Imo State was reported to have been introduced from Cameroon, but it was different from ASF variants reported in Cameroon. Tet-15 and Tet-27 variants were recovered in Benue and Plateau States, while Tet-34 was were 
circulating in two States each within the study period and restricted to the North Central geographical region. While Tet-21b and Tet-31 were restricted to southeast geographical region of Nigeria.

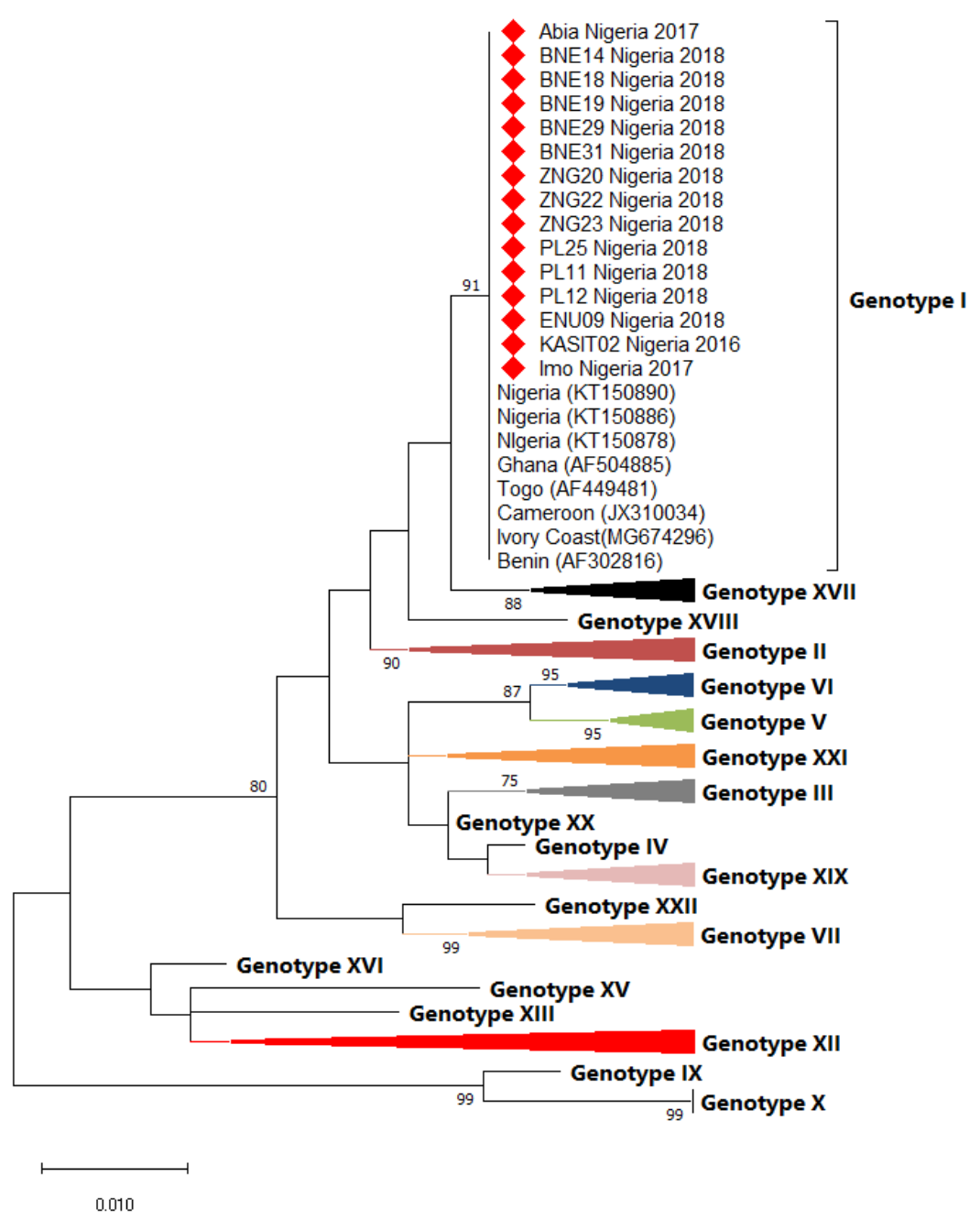

Fig2 : Phylogenetic tree of partial p72 protein encoded in B646L gene of Nigerian ASFV sequences (20162018). The tree was constructed in MEGA X using the Neighbor joining at 1000 bootstrap replicates. The Nigerian ASFV isolates from this study are marked red. 


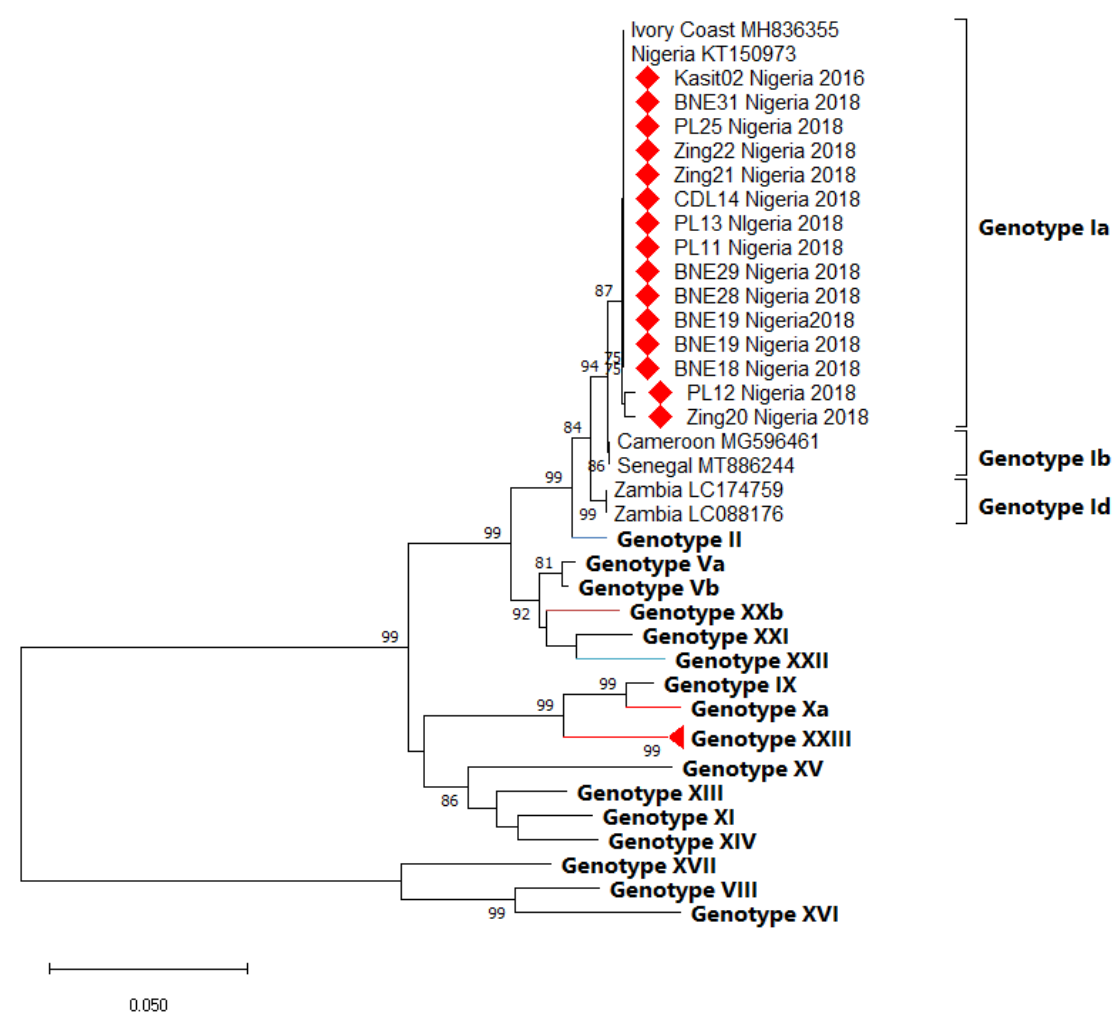

Fig. 3. Phylogenetic tree of full-length E183L gene encoding the $p 54$ protein of Nigeria ASFV isolates from 2016-2018.. The tree was constructed using MEGA X inferred by Minimum Evolution Method at 1000 bootstrap replicates. The Nigerian ASFV isolates of this study are noted in diamond and cluster with Genotype Ia

Table 2: Comparison of CVR profiles of B602L gene of African swine fever virus from outbreaks between 2016 and 2018 in Nigeria and other West African countries

\begin{tabular}{|c|c|c|c|c|c|c|c|}
\hline & $\begin{array}{l}\text { Sample } \\
\text { ID }\end{array}$ & Country & Year & $\begin{array}{l}\text { Accession } \\
\text { Number }\end{array}$ & Tetramer & Reference & $\begin{array}{l}\text { CVR } \\
\text { profile }\end{array}$ \\
\hline 1 & KASIT_ $_{-} 02$ & $\begin{array}{l}\text { Kafanchan, } \\
\text { Kaduna } \\
\text { State } \\
\text { Nigeria }\end{array}$ & 2016 & & Tet-20a & This Study & $\overline{\mathrm{ABNAAAACl}}$ \\
\hline 2 & PL03 & $\begin{array}{l}\text { K-Vom, } \\
\text { Plateau } \\
\text { State } \\
\text { Nigeria }\end{array}$ & 2016 & & Tet-15 & This study & ABNABNAA \\
\hline 3 & IMO06 & $\begin{array}{l}\text { Nekede, Imo } \\
\text { State } \\
\text { Nigeria }\end{array}$ & 2017 & & Tet-21b & This study & ABNAAAAA \\
\hline 4 & ENU09 & $\begin{array}{l}\text { Enugu, } \\
\text { Enugu } \\
\text { Nigeria }\end{array}$ & 2017 & & Tet-31 & This study & ABNAAAACl \\
\hline
\end{tabular}




\begin{tabular}{|c|c|c|c|c|c|c|c|}
\hline & $\begin{array}{l}\text { Sample } \\
\text { ID }\end{array}$ & Country & Year & $\begin{array}{l}\text { Accession } \\
\text { Number }\end{array}$ & Tetramer & Reference & $\begin{array}{l}\text { CVR } \\
\text { profile }\end{array}$ \\
\hline 5 & BNE14 & $\begin{array}{l}\text { Gboko } \\
\text { Benue } \\
\text { State }\end{array}$ & 2018 & & Tet-15 & This study & ABNABNAA \\
\hline 6 & PL10 & $\begin{array}{l}\text { Jos, Plateau } \\
\text { State } \\
\text { Nigeria }\end{array}$ & 2018 & & Tet-15 & This study & ABNABNAAA \\
\hline 7 & BEN19 & $\begin{array}{l}\text { Otukopo, } \\
\text { Benue State } \\
\text { Nigeria }\end{array}$ & 2018 & & Tet-27 & This study & ABNAAAACE \\
\hline 8 & PL 20 & $\begin{array}{l}\text { Jos } \\
\text { Plateau } \\
\text { State }\end{array}$ & 2018 & & Tet-27 & $\begin{array}{l}\text { This } \\
\text { Study }\end{array}$ & $\mathrm{ABNAAAACE}$ \\
\hline 9 & ZNG21 & $\begin{array}{l}\text { Zing, Taraba } \\
\text { State } \\
\text { Nigeria }\end{array}$ & 2018 & & Tet-34 & This study & ABNAAAACE \\
\hline 10 & PL24 & $\begin{array}{l}\text { Jos, Plateau } \\
\text { State } \\
\text { Nigeria }\end{array}$ & 2018 & & Tet-34 & This study & $\mathrm{ABNAAAACE}$ \\
\hline 11 & PL12 & $\begin{array}{l}\text { Jos, Plateau } \\
\text { State } \\
\text { Nigeria }\end{array}$ & 2018 & & Tet-34 & This study & $\mathrm{ABNAAAACE}$ \\
\hline 12 & PL13 & $\begin{array}{l}\text { Jos, Plateau } \\
\text { State } \\
\text { Nigeria }\end{array}$ & 2018 & & Tet-34 & This study & ABNAAAACE \\
\hline 13 & PL14 & $\begin{array}{l}\text { Jos, Plateau } \\
\text { State } \\
\text { Nigeria }\end{array}$ & 2018 & & Tet-34 & This study & $\mathrm{ABNAAAACE}$ \\
\hline 14 & PL25 & $\begin{array}{l}\text { Jos, Plateau } \\
\text { State } \\
\text { Nigeria }\end{array}$ & 2018 & & Tet-34 & This study & ABNAAAACE \\
\hline 15 & BNE28 & $\begin{array}{l}\text { Yandev, } \\
\text { Benue } \\
\text { Nigeria }\end{array}$ & 2018 & & Tet-27 & This Study & ABNAAAACE \\
\hline 16 & BNE18 & $\begin{array}{l}\text { Yandev, } \\
\text { Benue State } \\
\text { Nigeria }\end{array}$ & 2018 & & Tet-27 & This study & ABNAAAACE \\
\hline 17 & $\mathrm{CAM} / 89$ & Cameroon & 1989 & AF513045 & Tet-20a & $\begin{array}{l}\text { Wade et } \\
a l ., 2019\end{array}$ & ABNAAAACE \\
\hline 18 & Nig08/BNGb9 & $\begin{array}{l}\text { Gboko } \\
\text { Benue State } \\
\text { Nigeria }\end{array}$ & 2008 & AGC93420 & Tet-22a & $\begin{array}{l}\text { Alkhamis et } \\
\text { al. } 2018\end{array}$ & ABNAAAACA \\
\hline 19 & $\begin{array}{l}\text { NIG_- }_{-} \\
\text {BNGBT2 }\end{array}$ & $\begin{array}{l}\text { Benue State } \\
\text { Nigeria }\end{array}$ & 2009 & KT150924 & Tet-20b & $\begin{array}{l}\text { Luka et } a l, \text {, } \\
2015\end{array}$ & ABNAAAAAC \\
\hline 20 & $\begin{array}{l}\text { NIG_- } \\
\text { ABDPOSASF } 5\end{array}$ & $\begin{array}{l}\text { Jos Plateau } \\
\text { State } \\
\text { Nigeria }\end{array}$ & 2011 & KT150923 & Tet-20b & $\begin{array}{l}\text { Luka et al, } \\
2015\end{array}$ & ABNAAAAAC \\
\hline
\end{tabular}




\begin{tabular}{|c|c|c|c|c|c|c|c|}
\hline & $\begin{array}{l}\text { Sample } \\
\text { ID }\end{array}$ & Country & Year & $\begin{array}{l}\text { Accession } \\
\text { Number }\end{array}$ & Tetramer & Reference & $\begin{array}{l}\text { CVR } \\
\text { profile }\end{array}$ \\
\hline 21 & $\begin{array}{l}\text { NIG_- } \\
\text { KDKASITLN2 }\end{array}$ & $\begin{array}{l}\text { Kafanchan, } \\
\text { Kaduna } \\
\text { State } \\
\text { Nigeria }\end{array}$ & 2012 & KT150938 & Tet-20b & $\begin{array}{l}\text { Luka et al, } \\
2015\end{array}$ & $\overline{\mathrm{ABNAAAAA}}$ \\
\hline 22 & $\begin{array}{l}\text { NIG_- } \\
\text { IMOWR01 }\end{array}$ & $\begin{array}{l}\text { Owerri Imo } \\
\text { State } \\
\text { Nigeria }\end{array}$ & 2013 & KT150934 & Tet-20b & $\begin{array}{l}\text { Luka et al, } \\
2015\end{array}$ & ABNAAAAA \\
\hline 23 & Nig08/BNGb24 & $\begin{array}{l}\text { Gboko, } \\
\text { Benue State } \\
\text { Nigeria }\end{array}$ & 2008 & AGC93421 & Tet-22b & $\begin{array}{l}\text { Alkhamis et } \\
\text { al. } 2018\end{array}$ & ABNAAAAAC \\
\hline 24 & $\begin{array}{l}\text { Nigeria_- } \\
\text { (GQ427185) }\end{array}$ & Nigeria & 2008 & GQ427185 & Tet-20a & $\begin{array}{l}\text { Owolodun } \\
\text { et al } 2010\end{array}$ & ABNAAAACI \\
\hline 25 & Nig08/BNGb15 & $\begin{array}{l}\text { Gboko/Benue } \\
\text { State }\end{array}$ & 2008 & & Tet-27 & $\begin{array}{l}\text { Couacy- } \\
\text { Hymann } \\
\text { et al., } \\
2019 .\end{array}$ & ABNAAAACI \\
\hline 26 & Nig08/LAOk1 & $\begin{array}{l}\text { Lagos } \\
\text { Nigeria }\end{array}$ & 2008 & $\mathrm{KC} 112590$ & Tet-36 & $\begin{array}{l}\text { Alkhamis et } \\
\text { al. }(2018\end{array}$ & ABNAAAACI \\
\hline 27 & Nig08/LAOk2 & $\begin{array}{l}\text { Lagos } \\
\text { Nigeria }\end{array}$ & 2008 & AGC93424 & Tet-37 & $\begin{array}{l}\text { Alkhamis et } \\
\text { al. }(2018\end{array}$ & ABNAAAACH \\
\hline 35 & $\mathrm{CMR} /$ sangm $2 \mathrm{a}$ & Cameroon & 2010 & & Tet-20b & $\begin{array}{l}\text { Wade } \text { et } \\
\text { al. } 2019\end{array}$ & ABNAAAAAC \\
\hline 39 & Ben09/AGL1 & Benin & 2009 & & Tet-22b & $\begin{array}{l}\text { Alkhamis } \\
\text { et al. } 2018\end{array}$ & ABNAAAAAC \\
\hline 40 & Tog09/P1 & Togo & 2009 & & Tet-22b & $\begin{array}{l}\text { Alkhamis } \\
\text { et al. } 2018\end{array}$ & ABNAAAAAC \\
\hline 41 & $\mathrm{IC} / 1 / 96$ & $\begin{array}{l}\text { Ivory } \\
\text { Coast }\end{array}$ & 1996 & AF513036 & Tet-36 & $\begin{array}{l}\text { Couacy- } \\
\text { Hymann } \\
\text { et al., } \\
2019\end{array}$ & ABNAAAACI \\
\hline 42 & $\begin{array}{l}\text { Ben_97/6 } \\
\text { Benin }\end{array}$ & Benin & 1997 & CAJ90780 & Tet-36 & $\begin{array}{l}\text { Nix et al. } \\
2006\end{array}$ & ABNAAAACI \\
\hline 43 & $\begin{array}{l}\text { Nig29_- } \\
\text { LGTT }\end{array}$ & Plateau/Langt & arge15 & KT96137 & Tet-17a & $\begin{array}{l}\text { Luka et } \\
\text { al., } 2016\end{array}$ & ABNABNAA \\
\hline 44 & $\begin{array}{l}\text { Nig30_- } \\
\text { LGTT }\end{array}$ & Plateau/Langt & argeg15 & KT961376 & Tet-17b & $\begin{array}{l}\text { Luka et } \\
\text { al., } 2016\end{array}$ & ABNAAAAC \\
\hline 45 & Nig9_JS16_1 & $\begin{array}{l}\text { Plateau/Jos } \\
\text { Nigeria }\end{array}$ & 2013 & KT961365 & Tet-48 & $\begin{array}{l}\text { Luka et al., } \\
2016\end{array}$ & ABNAAAACI \\
\hline
\end{tabular}

Notes . CVR codes as previously described: $\mathrm{CAST} / \mathrm{CVST} / \mathrm{CTST}=\mathrm{A}, \mathrm{CADT} / \mathrm{CTDT}=\mathrm{B}, \mathrm{GAST} / \mathrm{GANT}$ $=\mathrm{C}, \mathrm{CASM}=\mathrm{D}, \mathrm{CANT}=\mathrm{F}, \mathrm{CTNT}=\mathrm{G}, \mathrm{NEDT}=\mathrm{M}, \mathrm{NVDT} / \mathrm{NVGT} / \mathrm{NVNT}=\mathrm{N}, \mathrm{NANI} / \mathrm{NADI} / \mathrm{NASI}$ $=\mathrm{O}, \mathrm{RAST}=\mathrm{H}, \mathrm{SAST}=\mathrm{S}, \mathrm{NVNT}=\mathrm{T}, \mathrm{NAST} / \mathrm{NADT} / \mathrm{NANT}=\mathrm{V}$ and $\mathrm{SADT} / \mathrm{SVDT}=\mathrm{W}$.

\section{Discussion}

This study presents an update on ASFV circulating in Nigeria based on the characterization of three genes of the ASFV from samples collected during suspected ASF disease outbreaks between 2016- 20180. Phylogeny of ASFV identified genotype I and Ia from samples analyzed based on the $B 646 L$ and $E 183 L$ genes which show high stability of these regions of the virus. However, sequence analysis of the hypervariable CVR 
encoded within B602L gene revealed six ASFV genotype I variants, three of which were new (Tet-21b, Tet$31 \&$ Tet-34) and never reported in Nigeria nor any of the West African countries. Earlier genetic studies had recovered 11 ASFV genotype I variants in Nigeria (Tet-15, Tet-17a, Tet-17b, Tet-20a, Tet-20b, Tet-21a, Tet-22, Tet-27, Tet-29, Tet-32, Tet-36, Tet-48) (Owolodun et al., 2010; Luka et al., 2016) (Table 2). With 3 newly recovered variants in this study, 14 ASFV genotype I TRS variants have now been recovered in Nigeria. Interestingly, earlier ASFV genotype I variants like Tet-36 recovered from the first outbreak in 1997 have been displaced by newer TRS variants. In this study, Tet-15, Tet-27, and Tet-34 were the most widely distributed ASFV variants co-circulating in Benue and Plateau States. (Table 2, Fig.1). These findings differ from the previous studies that reported Tet-36 as the dominant variant between 2003 and 2007 and Tet-20b was the most widespread TRS variant from 2007 to 2015(Luka et al., 2016). Tet-15 was first reported in Kaduna State in 2014 at a live pig market, but the variant has now spread to two other States based on the results from this study (Table 2). It is likely, Tet-15 spread from the live pig market in Kaduna State to Benue and Plateau States via trading of live pigs. Tet-27 was first recovered in 2003, the TRS variant has persisted and was recovered in several sites in Benue State in 2018 (Luka et al., 2016; Owolodun et al., 2010)(Table 2). Multiple variants of ASFV genotype I have been recovered in some countries in West and Central Africa. For instance, multiple ASFV genotype I variants have been recovered in Ivory Coast (4), Benin (4), Burkina Faso (7), Ghana (6), and Cameroon (4) (Luka et al., 2016; Couacy-Hymann et al., 2019; Wade et al., 2019). These findings suggest the CVR of B602Lof ASFV genotype I is prone to mutations in West and Central Africa. Furthermore, these mutations occur despite no documented evidence of the presence of sylvatic or tick ASFV transmission cycle in West and Central Africa (Luka et al., 2017). ASF outbreaks frequently occur in Nigeria with severe clinical outcomes, thereby affecting pig farmers' financial income and threatening food security. In this study, ASF outbreaks were reported in eight out of 30 pigproducing states of Nigeria (Fig 1). Although the number of outbreaks may be higher but were underreported due to a lack of financial compensation to pig farmers. Rather, farmers rapidly sell-off or slaughter sick pigs leading to further spread of the disease in Nigeria (Fasina et al., 2010). The ASF outbreaks between 2016 and 2018 in this study were both in intensively reared exotic pigs and free ranged NIP. Based on data collected, Plateau and Benue States seem to be hotspots of ASF in Nigeria as they have the highest number of recorded outbreaks. Epidemiological data collected in this study showed that basic biosecurity measures such as proper quarantine before the introduction of new stock and traffic control were not observed, leading to the introduction and spread of ASF in the affected pig farms. For instance, the ASF outbreak in Imo State was attributed to the illegal introduction of pigs into Nigeria from Cameroon, while that of Abia State was exacerbated by inadequate sanitary and biosecurity measures. Outbreaks in both States occurred in a cluster of pig farms. Clustering/communal pig farming is common practice in Nigeria, whereby pig farms are located close to each other, and farmers have access to each other's farms, share farmworkers and equipment. The ASF outbreaks reported in Zing, Taraba State affected 101 pig farmers leading to the death of 3,354 NIP breed (Fig 1). Although, field investigation did not reveal the source of the outbreak, nevertheless, the extensive husbandry system contributed to the spread of ASFV in the community. Interestingly, some of the NIPs survived the ASF outbreak with lower mortality rates of $45.6 \%$ compared to $73.7-80 \%$ for exotic breeds as recorded in this study. Some of the NIPs that survived the ASF outbreak were still alive and identified by farmers during a field visit to Zing, Taraba State, for another research study in 2019. Previously, studies in Nigeria have observed tolerance of NIP to ASFV, sometimes with no clinical signs or reduced death rates during outbreaks (Oluwole \& Omitogun, 2014). Studies in the Democratic Republic of Congo and Mozambique, reported indigenous pigs in endemic areas infected with the ASFV remained asymptomatic(Patrick et al., 2020 Penrinth et al.,2004; Patrick et al., 2020). Several risk factors have been identified as being responsible for the spread of ASFV in Nigeria, namely: poor husbandry system, live pigs trading and slaughtering of pigs on the farm and, movement of ASF infected and recovered animals (Fasina et al., 2012). Other factors include external sourcing of replacement stock, presence of ASF-infected farms within the neighbourhood of other farms and exchange of feed and farm tools by farmers and their workers (Olugasa \& Ijagbone, 2007; Awosanya et al., 2015). This study further confirms the importance of these risk factors in the spread and sustenance of the virus in the pig populations in Nigeria.

\section{Conclusion}


This study elucidates the continuous spread and emergence ASFV genotype I TRS variants in pig farming areas in Nigeria within three years of the study. Although phylogeny revealed genotype I, however, six variants were recovered following sequence analysis of CVR of $B 602 L$ gene. This study presents the first report of three of the variants that are co-circulating in four States in Nigeria. The increasing recovery of new variants of genotype I in Nigeria should be a source of serious concern, particularly for a stable DNA virus like ASFV. But the epidemiological implications of the findings are unknown and need further investigation.

\section{Acknowledgments}

This research was funded by the African Union Commission(AURG-II-1-196-2016). The authors acknowledge the staff of the National Veterinary Research Institute Vom for the technical assistance.

\section{Ethical approval}

This study was approved by National Veterinary Research Institute Animal Ethics Committee Vom, Nigeria (AEC/03/26/16).

\section{Conflict of Interest}

The authors of this study declare that they have no conflict of interests.

\section{References}

Achenbach, J. E., Gallardo, C., Nieto-Pelegrín, E., Rivera-Arroyo, B., Degefa-Negi, T., Arias, M., Jenberie, S., Mulisa, D. D., Gizaw, D., Gelaye, E., Chibssa, T. R., Belaye, A., Loitsch, A., Forsa, M., Yami, M., Diallo, A., Soler, A., Lamien, C. E., \& Sánchez-Vizcaíno, J. M. (2017). Identification of a New Genotype of African Swine Fever Virus in Domestic Pigs from Ethiopia. Transboundary and Emerging Diseases ,64 (5), 1393-1404. https://doi.org/10.1111/tbed.12511

Adedeji, A. J., Luka, P. D., Atai, R. B., Olubade, T. A., Hambolu, D. A., Ogunleye, M. A., Muwanika, V. B., \& Masembe, C. (2021). First-Time Presence of African Swine Fever Virus Genotype II in Nigeria.Microbiology Resource Announcements , 10 (26). https://doi.org/10.1128/MRA.00350-21

Agüero, M., Fernández, J., Romero, L., Sánchez Mascaraque, C., Arias, M., \& Sánchez-Vizcaíno, J. M. (2003). Highly Sensitive PCR Assay for Routine Diagnosis of African Swine Fever Virus in Clinical Samples. Journal of Clinical Microbiology , 41 (9), 4431-4434. https://doi.org/10.1128/JCM.41.9.4431-4434.2003

Alonso, C., Borca, M., Dixon, L., Revilla, Y., Rodriguez, F., Escribano, J. M., \& ICTV Report Consortium. (2018). ICTV Virus Taxonomy Profile: Asfarviridae. Journal of General Virology , 99 (5), 613-614. https://doi.org/10.1099/jgv.0.001049

Awosanya, E. J., Olugasa, B., Ogundipe, G., \& Grohn, Y. T. (2015). Sero-prevalence and risk factors associated with African swine fever on pig farms in southwest Nigeria. BMC Veterinary Research ,11 (1), 133. https://doi.org/10.1186/s12917-015-0444-3

Bastos, A. D. S., Penrith, M.-L., Crucière, C., Edrich, J. L., Hutchings, G., Roger, F., Couacy-Hymann, E., \& R.Thomson, G. (2003). Genotyping field strains of African swine fever virus by partial p72 gene characterisation. Archives of Virology , 148 (4), 693-706. https://doi.org/10.1007/s00705-002-0946-8

Blome, S., Franzke, K., \& Beer, M. (2020). African swine fever - A review of current knowledge. Virus Research, 287 , 198099. https://doi.org/10.1016/j.virusres.2020.198099

Brown, A.-A., Penrith, M. L., Fasina, F. O., \& Beltran-Alcrudo, D. (2017). The African swine fever epidemic in West Africa, 1996-2002. Transboundary and Emerging Diseases , 65 (1), 64-76. https://doi.org/10.1111/tbed.12673

Costard, S., Mur, L., Lubroth, J., Sanchez-Vizcaino, J. M., \& Pfeiffer, D. U. (2013). Epidemiology of African swine fever virus. Virus Research, 173 (1), 191-197. https://doi.org/10.1016/j.virusres.2012.10.030 
Couacy-Hymann, E., Kouakou, K. V., Achenbach, J. E., Kouadio, L., Koffi, Y. M., Godji, H. P., Adje, K. E., Oulai, J., Pell-Minhiaud, H. J., \& Lamien, C. E. (2019). Re-emergence of genotype I of African swine fever virus in Ivory Coast. Transboundary and Emerging Diseases ,66 (2), 882-896. https://doi.org/10.1111/tbed.13098

Dellicour, S., Desmecht, D., Paternostre, J., Malengreaux, C., Licoppe, A., Gilbert, M., \& Linden, A. (2020). Unravelling the dispersal dynamics and ecological drivers of the African swine fever outbreak in Belgium. Journal of Applied Ecology , 57 (8), 1619-1629. https://doi.org/10.1111/1365-2664.13649

Dixon, L. K., Stahl, K., Jori, F., Vial, L., \& Pfeiffer, D. U. (2020). African Swine Fever Epidemiology and Control. Annual Review of Animal Biosciences , 8 (1), 221-246. https://doi.org/10.1146/annurev-animal021419-083741

Eustace Montgomery, R. (1921). On A Form of Swine Fever Occurring in British East Africa (Kenya Colony). Journal of Comparative Pathology and Therapeutics , 34, 159-191. https://doi.org/10.1016/S03681742(21)80031-4

Fasina, F. O., Agbaje, M., Ajani, F. L., Talabi, O. A., Lazarus, D. D., Gallardo, C., Thompson, P. N., \& Bastos, A. D. S. (2012). Risk factors for farm-level African swine fever infection in major pig-producing areas in Nigeria, 1997-2011. Preventive Veterinary Medicine ,107 (1-2), 65-75. https://doi.org/10.1016/j.prevetmed.2012.05.011

Fasina, F. O., Shamaki, D., Makinde, A. A., Lombin, L. H., Lazarus, D. D., Rufai, S. A., Adamu, S. S., Agom, D., Pelayo, V., Soler, A., Simon, A., Adedeji, A. J., Yakubu, M. B., Mantip, S., Benshak, A. J., Okeke, I., Anagor, P., Mandeng, D. C., Akanbi, B. O., .. Gallardo, C. (2010). Surveillance for African Swine Fever in Nigeria, 2006-2009: Surveillance for African Swine Fever, Nigeria. Transboundary and Emerging Diseases , no-no. https://doi.org/10.1111/j.1865-1682.2010.01142.x

Gallardo, C., Mwaengo, D. M., Macharia, J. M., Arias, M., Taracha, E. A., Soler, A., Okoth, E., Martin, E., Kasiti, J., \& Bishop, R. P. (2009). Enhanced discrimination of African swine fever virus isolates through nucleotide sequencing of the p54, p72, and pB602L (CVR) genes.Virus Genes , 38 (1), 85-95. https://doi.org/10.1007/s11262-008-0293-2

Gaudreault, N. N., Madden, D. W., Wilson, W. C., Trujillo, J. D., \& Richt, J. A. (2020). African Swine Fever Virus: An Emerging DNA Arbovirus. Frontiers in Veterinary Science , 7 , 215. https://doi.org/10.3389/fvets.2020.00215

Jori, F., Vial, L., Penrith, M. L., Perez-Sanchez, R., Etter, E., Albina, E., Michaud, V., \& Roger, F. (2013). Review of the sylvatic cycle of African swine fever in sub-Saharan Africa and the Indian ocean. Virus Research , 173 (1), 212-227. https://doi.org/10.1016/j.virusres.2012.10.005

Kumar, S., Stecher, G., Li, M., Knyaz, C., \& Tamura, K. (2018). MEGA X: Molecular Evolutionary Genetics Analysis across Computing Platforms.Molecular Biology and Evolution , 35 (6), 1547-1549. https://doi.org/10.1093/molbev/msy096

Lubisi, B. A., Bastos, A. D. S., Dwarka, R. M., \& Vosloo, W. (2005). Molecular epidemiology of African swine fever in East Africa.Archives of Virology , 150 (12), 2439-2452. https://doi.org/10.1007/s00705-005-0602-1

Luka, P. D., Achenbach, J. E., Mwiine, F. N., Lamien, C. E., Shamaki, D., Unger, H., \& Erume, J. (2016). Genetic Characterization of Circulating African Swine Fever Viruses in Nigeria (2007-2015). Transboundary and Emerging Diseases , 64 (5), 1598-1609. https://doi.org/10.1111/tbed.12553

Luka, P. D., Mwiine, F. N., Yakubu, B., Erume, J., Perez-Sanchez, R., Unger, H., \& Shamaki, D. (2017). African Swine Fever Virus Transmission Cycle in Nigeria: Assessment of Domestic Pig-Soft Tick Contact through Detection of Antibodies against Ornithodoros moubata Salivary Antigen TSGP1. Veterinary Sciences: Research and Reviews , 3 (1), 6-12. https://doi.org/10.17582/journal.vsrr/2017.3.1.6.12 
Malogolovkin, A., Burmakina, G., Titov, I., Sereda, A., Gogin, A., Baryshnikova, E., \& Kolbasov, D. (2015). Comparative Analysis of African Swine Fever Virus Genotypes and Serogroups. Emerging Infectious Diseases , 21 (2), 312-315. https://doi.org/10.3201/eid2102.140649

Malogolovkin, A., Burmakina, G., Tulman, E. R., Delhon, G., Diel, D. G., Salnikov, N., Kutish, G. F., Kolbasov, D., \& Rock, D. L. (2015). African swine fever virus CD2v and C-type lectin gene loci mediate serological specificity. Journal of General Virology,96 (4), 866-873. https://doi.org/10.1099/jgv.0.000024

Mulumba-Mfumu, L. K., Saegerman, C., Dixon, L. K., Madimba, K. C., Kazadi, E., Mukalakata, N. T., Oura, C. A. L., Chenais, E., Masembe, C., Stahl, K., Thiry, E., \& Penrith, M. L. (2019). African swine fever: Update on Eastern, Central and Southern Africa. Transboundary and Emerging Diseases, tbed.13187. https://doi.org/10.1111/tbed.13187

Nix, R. J., Gallardo, C., Hutchings, G., Blanco, E., \& Dixon, L. K. (2006). Molecular epidemiology of African swine fever virus studied by analysis of four variable genome regions. Archives of Virology ,151 (12), 2475-2494. https://doi.org/10.1007/s00705-006-0794-z

Odemuyiwa, S. O., Adebayo, I. A., Ammerlaan, W., Ajuwape, A. T. P., Alaka, O. O., Oyedele, O. I., Soyelu, K. O., Olaleye, D. O., Otesile, E. B., \& Muller, C. P. (2000). An Outbreak of African Swine Fever in Nigeria: Virus Isolation and Molecular Characterization of the VP72 Gene of a First Isolate from West Africa . 20 (2), 139-142.

Olugasa, B. O., \& Ijagbone, I. F. (2007). Pattern of spread of African swine fever in south-western Nigeria, 1997-2005. Vet Ital ,43, 9.

Oluwole, O. O., \& Omitogun, G. O. (2014). Polymerase Chain Reaction Detection of ASFV Infection in Nigerian Indigenous Pig. American Journal of Molecular Biology , 04 (03), 159-162. https://doi.org/10.4236/ajmb.2014.43017

Owolodun, O. A., Bastos, A. D. S., Antiabong, J. F., Ogedengbe, M. E., Ekong, P. S., \& Yakubu, B. (2010). Molecular characterisation of African swine fever viruses from Nigeria (2003-2006) recovers multiple virus variants and reaffirms CVR epidemiological utility. Virus Genes , 41 (3), 361-368. https://doi.org/10.1007/s11262-009-0444-0

Patrick, B. N., Machuka, E. M., Githae, D., Banswe, G., Amimo, J. O., Ongus, J. R., Masembe, C., Bishop, R. P., Steinaa, L., Djikeng, A., \& Pelle, R. (2020). Evidence for the presence of African swine fever virus in apparently healthy pigs in South-Kivu Province of the Democratic Republic of Congo. Veterinary Microbiology , 240 , 108521. https://doi.org/10.1016/j.vetmic.2019.108521

Penrith, M.-L., \& Vosloo, W. (2009). Review of African swine fever: Transmission, spread and control : review article. Journal of the South African Veterinary Association , 80 (2), 58-62. https://doi.org/10.4102/jsava.v80i2.172

Phologane, S. B., Bastos, A. D. S., \& Penrith, M.-L. (2005). Intra- and Inter-Genotypic Size Variation in the Central Variable Region of the 9RL Open Reading Frame of Diverse African Swine Fever Viruses. Virus Genes , 31 (3), 357-360. https://doi.org/10.1007/s11262-005-3254-z

Quembo, C. J., Jori, F., Vosloo, W., \& Heath, L. (2018). Genetic characterization of African swine fever virus isolates from soft ticks at the wildlife/domestic interface in Mozambique and identification of a novel genotype. Transboundary and Emerging Diseases ,65 (2), 420-431. https://doi.org/10.1111/tbed.12700

Tizhe, E. V., Luka, P. D., Adedeji, A. J., Tanko, P., Gurumyen, G. Y., Buba, D. M., Tizhe, U. D., Bitrus, A. A., Oragwa, A. O., Shaibu, S. J., Unanam, E. S., Igbokwe, I. O., Akpavie, S. O., \& Njoku, C. O. (2020).Laboratory diagnosis of a new outbreak of acute African swine fever in smallholder pig farms in Jos, Nigeria . 9.

Wade, A., Achenbach, J. E., Gallardo, C., Settypalli, T. B. K., Souley, A., Djonwe, G., Loitsch, A., Dauphin, G., Ngang, J. J. E., Boyomo, O., Cattoli, G., Diallo, A., \& Lamien, C. E. (2019). Genetic character- 
ization of African swine fever virus in Cameroon, 2010-2018. Journal of Microbiology , 57 (4), 316-324. https://doi.org/10.1007/s12275-019-8457-4 